\title{
Intramedullary Spinal Cord Metastasis from Malignant Mesenchymal Tumor: Detection with FDG-PET/CT
}

\author{
Malign Mezenkimal Tümörde Intramedüller Omurilik Metastazının FGD-PET/BT ile Tespiti
}

\author{
Müge Öner Tamam1, Cüneyt Tamam², Düzgün Yıldırım³, Mehmet Mülazımoğlu1, Gülçin Kamalı4 \\ IOkmeydanı Training and Research Hospital, Clinic of Nuclear Medicine, Istanbul, Turkey \\ 2Kasımpaşa Military Hospital, Clinic of Orthopedics and Traumatology, Istanbul, Turkey \\ ${ }^{3}$ Kasımpaşa Military Hospital, Clinic of Radiology, Istanbul, Turkey \\ ${ }^{4}$ Okmeydanı Training and Research Hospital, Clinic of Pathology, Istanbul, Turkey
}

\begin{abstract}
Intramedullary spinal cord metastasis is very rare. In this study, we present the case of a 32-year-old male patient with a 2-month history of bilateral lower extremity weakness. Initial magnetic resonance imaging of the dorsal spine showed abnormal thickening of the dorsal spinal cord at the level of the T1-2 bodies. FDG-PET/CT images revealed a hypermetabolic lesion in the spinal cord at this level. This patient had an intramedullary spinal cord metastasis, a rare form of metastatic disease, secondary to malignant mesenchymal tumor.
\end{abstract}

Key words: Fluorodeoxyglucose F18, positron-emission tomography, spinal cord, metastasis, intramedullary, malignant mesenchymal tumor

Conflicts of Interest: The authors reported no conflict of interest related to this article.

\section{Özet}

Intramedüller spinal kord metastazı çok nadirdir. Bu çalışmada, 2 aydır bilateral alt ekstremite zayıflığı olan 32 yaşındaki erkek olguyu sunduk. Yapılan Magnetik Resonans görüntülemede torakal vertebra 1-2 seviyesinde omurilikte anormal kalınlaşma görüldü. FDG-PET/BT görüntüler T1-2 seviyesinde omurilikte hipermetabolik lezyon izlendi. Bu hastada metastatik hastalığın nadir formu olan malign mezenkimal tümöre ikincil intramedüller spinal kord metastazıdır.

Anahtar Kelimeler: Florodeoksiglukoz F18, pozitron-emisyon tomografisi, omurilik, metastaz, intramedüller, malign mezenkimal tümör

Çıkar Çatışması: Yazarlar bu makale ile ilgili olarak herhangi bir çıkar çatışması bildirmemiştir.

\section{Introduction}

Intramedullary spinal cord metastasis is very rare, accounting for only $0.9-2.1 \%$ of all spinal cord metastases. They are usually incidental findings during autopsy, and the low incidence may be attributed to the fact that the spinal cord is not a frequently examined site during routine autopsy (1). The majority of intramedullary metastases are from lung cancer, representing approximately $50 \%$ of these lesions. Intramedullary metastases have also been frequently reported to arise from primary lesions such as breast carcinoma, melanoma, lymphoma, renal cell carcinoma, colorectal carcinoma, and unknown primary tumors (2).

Address for Correspondence: Müge Öner Tamam MD, Okmeydanı Training and Research Hospital, Clinic of Nuclear Medicine, İstanbul, Turkey Phone: +90 5324082376 E-mail: mugeoner@yahoo.com Received: 23.10.2012 Accepted: 25.07.2013 
This patient had an intramedullary spinal cord metastasis, a rare form of metastatic disease, secondary to malignant mesenchymal tumor.

\section{Case Report}

A 32-year-old male patient had been treated with systemic agents and local palliative radiotherapy after surgical excision for left cervical malignant mesenchymal tumor. After six months, a magnetic resonance imaging (MRI) was performed for complaints of weakness in the legs and difficulty in walking.

Sagittal T1w images showed isointense but abnormal thickening of the dorsal spinal cord at the level of the T1-T2 bodies (Figure 1a) (between arrows). T2w sagittal image at the same section showed intradural and intramedullary position of the pathology. A probably necrotic focus was seen relatively hyper-intense at the lower border of this lesion (long arrow). Syrinx formation was also present near the upper and lower boundaries of the tumor (Figure 1b) (small arrows). After intravenous gadolinium administration, fat saturated sagittal T1 $w$ image demonstrated dense contrast enhancement of the lesion which was diagnosed as dorsal spinal cord metastasis from a known primary malignancy (Figure 1c) (mesenchymal tumor, between arrows).

A whole body 18F-fluoro-2-deoxyglucose positron emission tomography/computed tomography (FDG-PET/ CT) (Esoft workstation, Siemens Biograph 6; Chicago, USA) was applied in order to investigate additional metastatic sites. After 6 hours of fasting and with serum glucose level of $97 \mathrm{mg} / \mathrm{dL}$, the patient was injected with $407 \mathrm{MBq}(11 \mathrm{mCi})$ of F-18 FDG intravenously. Transaxial (a) and sagittal (b) FDG-PET and fused images showed intense FDG accumulation (the maximum standardized uptake value (SUVmax): 15.7) along T1-2 spinal cord with no other sites of metastatic spread (Figure 2). Excisional biopsy of the intradural-intramedullary mass in T1-2 vertebrea revealed malignant mesenchymal tumor (Figure 3).

\section{Literature Review and Discussion}

Intramedullary spinal cord metastases are very rare, usually solitary lesions, comprising $0.9-5.0 \%$ of all spinal cord metastases, and $4 \%$ to $9 \%$ of all spinal cord tumors. They are usually incidental findings during autopsy, and the low incidence may be attributed to the fact that the spinal cord is not a frequently examined site during routine autopsy (1). It clinically manifests in only $0.1-0.4 \%$ of cancer patients, most commonly in lung cancer patients, followed by breast cancer in 11\%, melanoma in 5\%, renal cell cancer in $4 \%$, colorectal cancer in $3 \%$, lymphoma in $3 \%$, thyroid cancer in $2 \%$, and ovarian cancer in $1 \%$. Approximately $3 \%$ are secondary to an unknown primary $(3,4,5,6,7,8,9)$.
The differential diagnosis for intramedullary spinal lesions on imaging studies include pilocytic astrocytoma, radiation myelopathy, sarcoidosis, gliomas, neuropathy, primary spinal epidural non-Hodgkin lymphoma, vascular malformations, and rarely spinal infections such as tuberculosis $(9,10,11,12,13,14)$. The routine imaging modality generally used for the diagnosis of intramedullary spinal cord metastasis is MRI. Other imaging techniques (CT, PET/CT, and angiography) are of limited significance $(15,16)$. PET has a sensitivity rate of $96 \%$ in detecting spinal metastasis. This rate is even higher when combined with CT scan (17). As previously mentioned, FDG-PET/CT was used in our case in order to evaluate distant metastases.

The clinical presentation of symptomatic patients range from minor neurological symptoms to major symptoms,
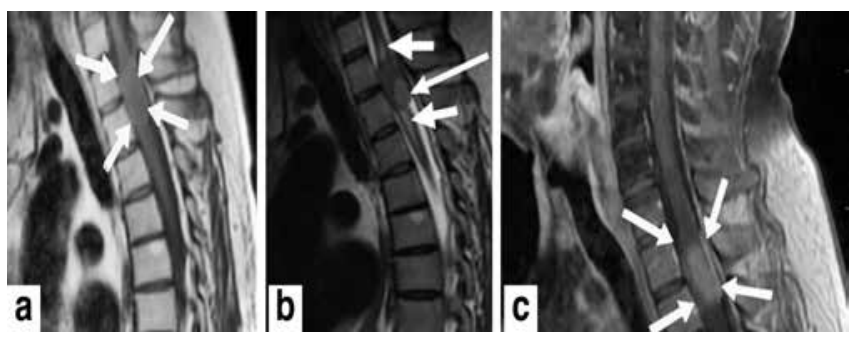

Figure 1a, 1b, 1c. Magnetic resonance imaging revealed a lesion suspicious for metastasis on T1-2 vertebrae

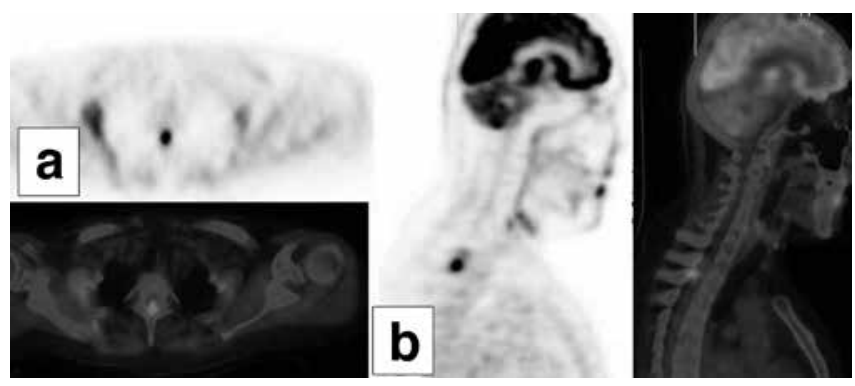

Figure 2. Transaxial (a) and Sagittal (b) FDG-PET and fused images showed intense FDG accumulation (the maximum standardized uptake value (SUVmax): 15.7) along the T1-2 spinal cord with no other sites of metastatic spread

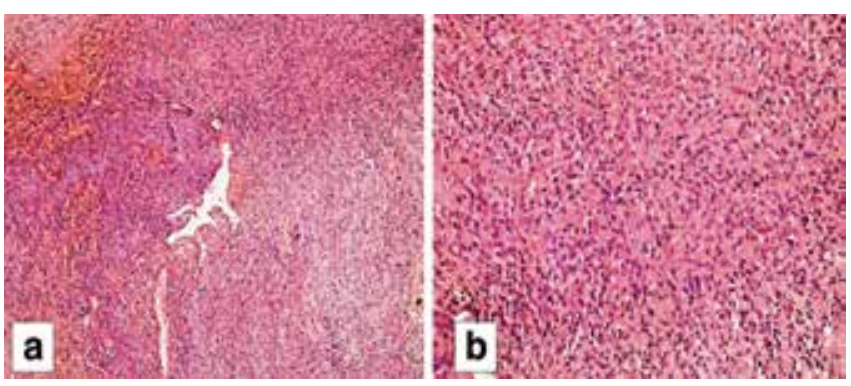

Figure 3. Tumor composed of bundles of spindle cells with cellular atypia and nuclear pleomorphism with areas of hemorrhage and focal necrosis (x100 Hematoxylin and eosin (H\&E)) (a). Tumor composed of spindle cells with $\mathrm{HE}(\mathrm{x} 200)$ palisade sequences (b) 
mostly presenting rapid progressive neurological deficits that require immediate further examination. With mortality rate is $80 \%$ during the first three to four months after the appearance of the first symptom; the overall prognosis is poor (9).

This patient had an intramedullary spinal cord metastasis, a rare form of metastatic disease, secondary to malignant mesenchymal tumor.

\section{References}

1. Amin R. Intramedullary spinal metastasis from carcinoma of the cervix. A case report. The British Journal of Radiology 1999;72:89-91.

2. Potti $A$, Abdel-Raheem $M$, Levitt $R$, Schell DA, Mehdi SA. "Intramedullary spinal cord metastases (ISCM) and non-small cell lung carcinoma (NSCLC): clinical patterns, diagnosis and therapeutic considerations," Lung Cancer 2001;31:319-323.

3. Costigan DA, Winkelman MD. Intramedullary spinal cord metastasis. A clinicopathological study of 13 cases. J Neurosurg 1985;62:227-233.

4. Kaya RA, Dalkiliç T, Ozer F, Aydin Y. Intramedullary spinal cord metastasis: a rare and devastating complication of cancer - two case reports. NeurolMed Chir 2003;43:612-615.

5. Grem JL, Burgess J, Trump D. Clinical features and natural history of intramedullary spinal cord metastasis. Cancer 1985;56:2305-2314.

6. Edelson RN, Deck MD, Posner JB. Intramedullary spinal cord metastases. Clinical and radiographic findings in nine cases. Neurology 1972;22:1222-1231.

7. Nguyen NC, Sayed MM, Taalab K, Osman MM. Spinal cord metastases from lung cancer: detection with F-18 FDG PET/CT. Clin Nucl Med 2008;33:356-358.
8. Poggi MM Patronas $N$, Buttman JA Hewitt SM, Fuller B. Intramedullary spinal cord metastasis from renal cell carcinoma: detection by positron emission tomography. Clin Nucl Med 2001;26:837-839.

9. Kaballo MA, Brennan DD, El Bassiouni M, Hewitt SM, Fuller B. Intramedullary spinal cord metastasis from colonic carcinoma presenting as Brown-Séquard syndrome: a case report. J Med Case Reports 2011;5:342.

10. Wu PS, Yao WJ. F-18 FDG PET in spinal cord pilocytic astrocytoma. Clin Nucl Med 2010;35:649-650

11. Suga K, Matsunaga $N$, Yasuhiko K, Matsunaga N, Seki N, Kataoka $\mathrm{H}$, Taguchi T. F-18 FDG PET/CT findings in a case of spinal cord sarcoidosis. Clin Nucl Med 2011;36:382-385.

12. Chamroonrat W, Posteraro A, El-Haddad G, Zhuang $H$, Alavi A Radiation myelopathy visualized as increased FDG uptake on positron emission tomography. Clin Nucl Med 2005;30:560.

13. Cheng G, Chamroonrat W, Bing Z, Huang S, Zhuang H. Elevated FDG activity in the spinal cord and the sciatic nerves due to neuropathy. Clin Nucl Med 2009;34:950-951.

14. Ho L, Valenzuela D, Negahban A, Wassef H. Primary spinal epidural non-Hodgkin lymphoma demonstrated by FDG PET/CT. Clin Nucl Med 2010;35:487-489.

15. Kosmas C, Koumpou M, Nikolaou M, Katselis J, Soukouli G, Markoutsaki N, Kostopoulou V, Gaglia A, Mylonakis N, Karabelis A, Pectasides D. "Intramedullary spinal cord metastases in breast cancer: report of four cases and review of the literature. J Neurooncol 2005; 71:67-72.

16. Kalita O. Current Insights into Surgery for Intramedullary Spinal Cord Metastases: A Literature Review, Int J Surg Oncol 2011;2011:989506.

17. Metser U, Lerman H, Blank A, Lievshitz G, Bokstein F, Even-Sapir E. Malignant involvement of the spine: assessment by $18 \mathrm{~F}-\mathrm{FDG}$ PET/CT. J Nucl Med 2004:45:279-284. 